\title{
PENGUJIAN FRAUD PENTAGON TERHADAP RESIKO FINANCIAL FRAUDULENT REPORTING
}

\author{
Meiliana Jaunanda ${ }^{1}$ \\ Business School, Universitas Pelita Harapan \\ meiliana.jaunanda@uph.edu* \\ Daniel Peterson Silaban ${ }^{2}$ \\ Business School, Universitas Pelita Harapan \\ daniel.silaban@uph.edu
}

Diterima 29 April 2020

Disetujui 4 Agustus 2020

\begin{abstract}
The research to examine how much financial stability, financialtarget, externalpressure, natureof industry, ineffective monitoring, rationalization, capability and oship have effect partially and simultaneously to fraud pentagon. The research subjects used were manufacturing companies and were listed on the BEI in the 2014-2018 period. The results of this study are financial stability has a significant influence on fraudulent financial reporting. Rationalization has a significant effect on fraudulent financial reporting. Arrogance partially has a significant influence on fraudulent financial statements, financialtarget, externalpressure, natureof industry, ineffectivemonitoring, rationalization, capability and oship simultaneously have a significant effect on fraudulent financial statements.
\end{abstract}

\section{Key Words: Financial performance, Efficiency Operation, Firm Growth, Leverage, Fraud}

\section{PENDAHULUAN}

\subsection{Latar Belakang Masalah}

Di era digital saat ini, teknologi tidak memberikan jaminan suatu perusahaan memiliki sistem terintegrasi untuk menghindari kecurangan yang terjadi diperusahaan. Banyaknya kasus fraud yang terjadi didalam perusahaan dapat dikarenakan oleh individu atau pelaku fraud ataupun karena adanya kesempatan dari internal control yang buruk. banyaknya berita mengenai manipulasi laporan keuangan bukanlah sesuatu yang asing kembali. Laporan keuangan adalah komponen terpenting untuk pihak eskternal dan internal untuk mengambil keputusan yang dibutuhkan bagi perusahaan. Fraudulent financial statement memberikan dampak yang negatif, karena pelaporan keuangan yang salah maka pengambilan keputusanpun menjadi salah.

Persaingan yang ketat membuat perusahaan selalu memberikan laporan keuangan yang bagus dan menarik perhatian para investor, sehingga mereka secara sukarela memberikan modalnya kepada perusahaan. Namun tidak memungkiri bahwa pihak perusahaan bisa saja melakukan manipulasi laporan keuangan untuk menipu pihak eksternal terlebih investor dan kreditor, karena laporan keuangan yang bagus, dapat menarik perhatian pihak eskternal dalam memberikan dananya. Hal ini mengakibatkan pihak perusahaan secara sengaja menyajikan laporan keuangannya sebagus mungkin agar terlihat stabil dari sisi keuangan perusahaan dan menjalankan kinerja operasional perusahaan sehingga pada akhirnya resiko untuk melakukan fraud pun timbul.

ACFE menyatakan tindakan yang dilakukan oleh setiap individu ataupun secara berkelompok dan dilakukan secara sengaja sehingga memberikan dampak kerugian kepada 
individu atau entitas disebut sebagai tindak kecurangan atau fraud. Ernest \& Young (2009) melakukan penelitian dan menemukan fakta bahwa lebi dari 50\% kasus fraud dilakukan oleh top level manajemen karena manager yang paling berpengaruh terhadap tekanan dan peluang yang ada disekitar perusahaan sehingga lebih mudah untuk melakukan fraud.

AICPA lalu menerbitkan perarturan berupa yaitu SAS no.99 mengenai pertimbangan dalam kecurangan pada laporan keuangan. SAS No 99 dikeluarkan terkait skandal Enron dan WorldCom dan dibentuk untuk memberikan panduan bagi para auditor mengenai bagaimana cara mengidentifikasi fraud dalam laporan keuangan. Contohnya memberikan pemahaman bagi auditor untuk memperhatikan area beresiko seperti pengakuan pendapatan dan kontrol yang tidak dijalankan oleh manajemen. D. R. Cressey (1953) pada teori ini dijelaskan bawah ada tiga perilaku seseorang melakukan fraud yaitu adanya tekanan, adanya kesempatan, dan rasionalisasi yang disebut sebagai fraud triangle.

Wolfe \& Hermanson memperbaharui kembali teori dari fraud triangle dengan menambahkan satu komponen dalam hal pencegahan serta deteksi dalam fraud sehingga model tersebut menjadi pressure, opportunity, rationalization dan capability. Kemampuan seseorang dan sifat yang dimilikinya memiliki peran penting seseorang dalam melakukan fraud. Fraud yang bernilai material terjadi karena seseorang yang memiliki kemampuan yang tepat dan kedudukan yang baik didalam suatu organisasi. Peluang yang tersedia menjadi pintu masuk utnuk melakukan penipuan. (Wolfe \& Hermanson, 2014).

Lalu teori tersebut disempurnakan lagi oleh Crowe bahwa fraud diamond dapat ditingkatkan lagi menjadi lebih baik dengan menambah 1 elemennya yaitu arrogance (arogansi) sehingga model menjadi fraud pentagon. Fraud pentagon berfokus kepada kecurangan dilakukan oleh pihak CEO dan CFO dimana top level manajemen memiliki peluang yang lebih tinggi melakukan fraud dan $70 \%$ fraud yang dihasilkan mengakibatkan kerugiaan dalam jumlah besar. (Crowe, 2011).

Peneliti tertarik untuk meneliti fraud pentagon dan melakukan analisis terkait fraud yang terjadi dengan melakukan manipulasi laporan keuangan yang diukur dengan menggunakan pendekatan beneish model. Replikasi dari Mahenthiran (2017) dimana sektor penelitian yang dilakukan oleh Mahenthiran pada perusahaan dimalaysia namun pendekatannya tetap menggunakan benish-model, lalu hasil dari penelitaannya Financial stability, external pressure dan frequent number of CEO's picture berpengaruh signifikan terhadap fraudulent financial reporting. Sedangkan variabel lainnya yaitu, financial target, institusional ownership, ineffective monitoring, kualitas auditor eksternal, changes in auditor, pergantian direksi tidak berpengaruh signifikan terhadap fraudulent financial reporting

\section{TINJAUAN LITERATUR DAN HIPOTESIS}

\subsection{Grand Theory}

Agency Theory menjelaskan hubungan searah dimana principle dan agen dikatakan memiliki hubungan efisien apabila kedua belah pihak memiliki informasi yang simetris, sehingga tidak saling menguntungkan dengan menutupi informasi yang dimiliki. Disatu sisi, principle harus memenuhi kewajibannya yaitu membayar agent sesuai dengan kontrak dan kontribusinnya. Penyebab konflik agency theory karena adanya masalah antara principle dengan pihak agent dimana agent merasa beban untuk menanggung resiko dari kesalahan dalam pengambilan keputusan bukan tanggung jawabnya. Konflik berkepanjangan pihak manajer dan stakeholder dapat diminimalkan dengan cara manajer diberikan bayaran yang sesuai dengan kontrak atas tindakannya. (Jensen dan Meckling, 1976)

Fraud berarti tindakan seseorang atau sekelompok yang secara sengaja melakukan kecurangan sehingga salah saji material dalam laporan keuangan menjadi tinggi dan informasi 
tersebut menjadi bias. (AICPA, 2002) Pelaporan keuangan menyesatkan dilakukan dengan tujuan menipu para pengguna laporan dengan harapan apa yang dilakukan dapat memberikan keuntungan bagi pelaku fraud. Salah satu bentuk fraud yang paling memberikan dampak terbesar adalah fraudulent financial statement, dimana fraud jenis ini dilakukan dengan cara memanipulasi supporting dokumen, merepresentasikan yang salah ataupun penggunaan metode catatan akuntansi yang menyesatkan. Fraudulent financial statement sangat merugikan bagi pihak eksternal, khususnya kreditor dan investor karena perusahaan tersebut memiliiki resiko yang sangat tinggi namun tertutupi dengan laporan yang sangat bagus.

\subsection{Pengembangan Hipotesis}

1. Pengaruh FinancialStability terhadap FFR

kondisi perusahaan dapat dikategorikan stabil jika perusahaan bisa memenuhi kebutuhan operasionalnya baik yang sifatnya rutin ataupun mendesak. Sebaliknya jika perusahaan mengalami financial distress dan manajer tidak dapat memenuhi target yang ditetapkan dari atasan maka manajer akan memiliki kecenderungan fraud dengan melakukan memanipulasi laporan keuangan di area pendapatan. Financial Stability diproksikan dengan AGROW. (Sihombing \& Rahardjo, 2014) penelitian yang dilakukannya membuktikan bahwa FinancialStability(FS) berpengaruh positif terhadap FFR

\section{H1: Financial Stability Berpengaruh Positif Mendeteksi Fraudulent Financial Reporting.}

2. Pengaruh Financial Target terhadap FFR

Perusahaan yang memenuhi target penjualan dan keuntungaan dari produk dan jasa dengan menggunakan asset yang dimilikinya. Secara tidak langsung, perusahaan mampu menggunakan assetnya dan memberikan hasil yang positif disisi return yang didapat perusahaan. Sebaliknya tidak tercapainya targer perusahaan, manager akan memiliki kecenderungan memanipulasi laporan keuangan dan memastikan bahwa ia tetap mendapatkan bonus atas kinerjanya. Namun terdapat beberapa faktor yang tidak bisa dikendalikan atau bersifat force majeur sehingga target finansial bisa saja tidak dapat dicapai dan eksistensi nlai dari laporan keuangan diragukan. Financial Target diproksikan dengan ROA

\section{H2: Financial Target Berpengaruh Posiitf Untuk Mendeteksi Fraudulent Financial Reporting.}

3. Pengaruh External Pressure terhadap FFR

External pressure dapat dikatakan manager mendapatkan pressure dari pihak eskternal dan internal perusahaan. Pihak eksternal menuntut perusahaan harus dapat memenuhi pembayarannya kepada pihak kreditor dan memberikan return kepada investor. Pressure yang berlebihan memberikan stimulasi kepada manajer melakukan fraud. External Pressure diproksikan dengan DER. (Zaki, 2017) melakukan penelitiannya dan membuktikan bahwa External Pressure (EP) berpengaruh positif terhadap Fraudulent Financial

\section{H3: External Pressure Berpengaruh Positif Untuk Mendeteksi Fraudulent Financial Reporting.}

4. Pengaruh Ineffective Monitoring terhadap Fraudulent Financial Statement 
Perusahaan yang memiliki Board of Director yang independen dalam struktur organisasinya diyakini dapat memberikan pengaruh positif untuk menghindari kecurangan yang dilakukan oleh top level manajemen. Dewan komisaris independen secara tidak langsung dapat melakukan pengawasan lebih ketat dikarenakn bersifat independen dan tidak dipengaruhi dengan keadaaan lingkungan bisnis perusahaan. Aprilia (2017) melakukan penelitian dan membuktikan bahwa Ineffective Monitoring berpengaruh positif terhadap Fraudulent Financial Statement.

\section{H4: Ineffective Monitoring Berpengaruh Positif Untuk Mendeteksi Fraudulent Financial Reporting.}

5. Pengaruh Nature of Industry terhadap FFR

Adanya transaksi pihak berelasi lebih banyak dibandingan dengan pihak ketiga, menimbulkan faktor resiko keterlibatan manager dalam keputusan yang akan diambil sehingga hal ini dapat menimbulkan kesalahan yang disengaja dikemudian hari sehingga menghasilkan laporan keuangan yang memiliki tingkat materialitas tinggi. Manurung \& Hardika (2015) melakukan penelitian dan membuktikan bahwa Nature of Industri (NI) berpengaruh positif terhadap Fraudulent Financial Statement.

\section{H5: Ineffective Monitoring Berpengaruh Positif Untuk Mendeteksi Fraudulent Financial Reporting.}

6. Pengaruh Rationalization terhadap FFR

Total akrual adalah besaran yang ditentukan oleh manajer sehingga dapat memberikan peluang untuk melakukan manipulasi. Tingkat akrual biasanya memberikan nilai yang bervariasi berdasarkan estimasi dan keputusan dari manajemen terkait kebijakan suatu transaksi tertentu. Rationalization diproksikan dengan TATA. Amara, Amar, \& Jarboui, (2013) melakukan penelitian dan membuktikan bahwa Rationalization berpengaruh positif terhadap Fraudulent Financial Statement.

\section{H6: Rationalization Berpengaruh Positif Untuk Mendeteksi Fraudulent Financial Reporting.}

7. Pengaruh Capability terhadap FFR

Penipuan terjadi apabila seseorang memiliki kemampuan yang tepat dalam melaksanakan tahap demi tahap rencana detail untuk penipuan yang dilakukan. Perubahan direksi didalam perusahaan dapat menjadi salah satu antisipasi untuk mengeluarkan direksi yang terlibat kecurangan, sehingga penipu tidak memiliki kekuatan yang kuat untuk melihat celah dalam melakukan fraud. Capability diproksikan dengan Dchange. (Zaki, 2017) melakukan penelitiannya dan membuktikan bahwa Capability berpengaruh positif terhadap Fraudulent Financial Reporting.

H7: Capability Berpengaruh Untuk Mendeteksi Fraudulent Financial Reporting.

8. Pengaruh Arrogance terhadap FFR

Merupakan kondisi dimana manajemen mempunyai saham di perusahaan tempatnya bekerja dan merasa bahwa dirinya memiliki kekuasaan yang lebih. Sehingga, manajememn merasa yakin bahwa kebijakan dan prosedur perusahaan tidak berlaku untuknya dan dapat dilihat dari jumlah kepemilikan saham manajerial dari total jumlah saham yang dimiliki oleh perusahaan secara keseluruhan. Arrogance 
diproksikan dengan OSHIP. (Tessa, 2017) melakukan penelitiannya dan membuktikan bahwa Oship berpengaruh positif terhadap Fraudulent Financial Reporting.

H8: Arrogance Berpengaruh Untuk Mendeteksi Fraudulent Financial Reporting

\subsection{Kerangka Penelitian}

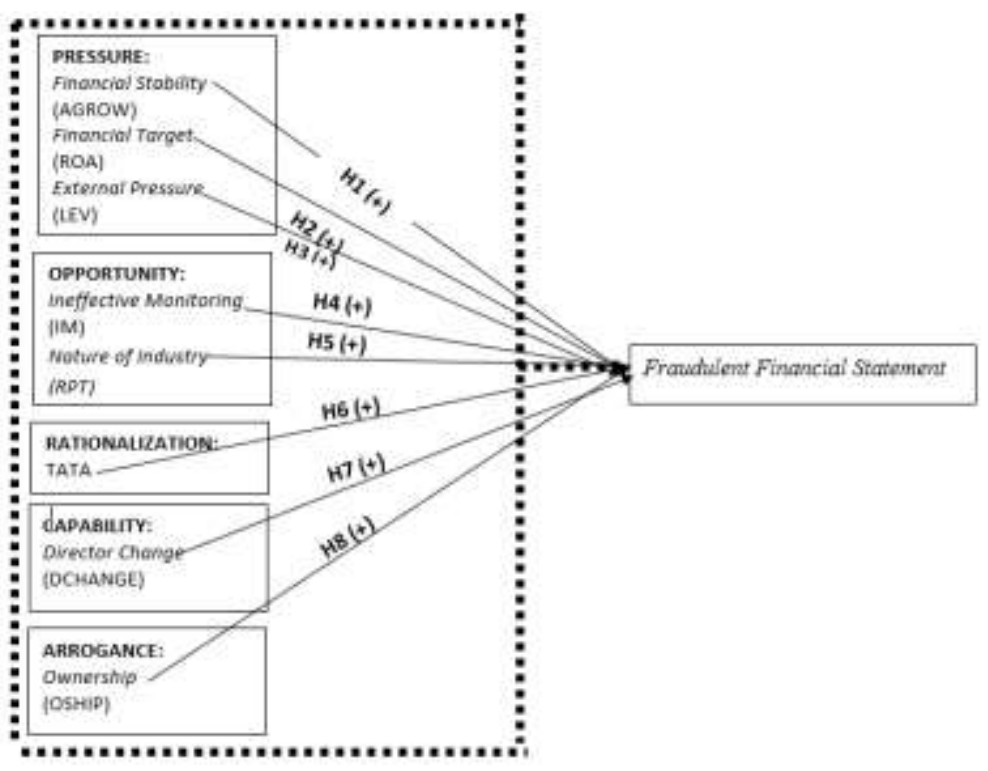

Gambar 1. Model Penelitian

\section{METODOLOGI DAN ANALISA DATA}

\subsection{Teknik Pengambilan Sample}

Populasi yang digunakan adalah perusahaan manufaktur terlisting di BEI selama periode 2014-2018. Sampel diambil dengan menggunakan purposive sampling. Berikut kriteria yang digunakan:

Tabel 1. Sampling Penelitian

\begin{tabular}{|l|l|}
\hline & Total Sampling \\
\hline $\begin{array}{l}\text { Perusahaan manufaktur yang berturut-turut terlisitng di BEI dari } \\
\text { periode 2014-2018 }\end{array}$ & 548 \\
\hline $\begin{array}{l}\text { Perusahaan menggunakan mata uang Rupiah secara berturut-turut } \\
\text { dari periode 2014-2018 }\end{array}$ & 508 \\
\hline $\begin{array}{l}\text { Perusahaan manufaktur yang menerbitkan laporan keuangan } \\
\text { audited dari periode 2015-2018 }\end{array}$ & 400 \\
\hline $\begin{array}{l}\text { Perusahaan yang memiliki nilai benish m-model dan tergolong } \\
\text { kategori } \text { fraud }\end{array}$ & 205 \\
\hline Sampling terkena uji outlier & -16 \\
\hline Total sampling setelah uji outlier & 189 \\
\hline
\end{tabular}




\subsection{Variabel Dependen}

Variabel dependen menggunakan fraudulent financial reporting menggunakan Beneish M-score yaitu terdiri dari 8 pengukuran rasio. Perhitunan beneish model, dengan perhitungan sebagai berikut:

$\mathrm{M}-\mathrm{Score}=-4.84+0.920 \mathrm{DSRI}+0.528 \mathrm{GMI}+0.404 \mathrm{AQI}+0.892 \mathrm{SGI}+0.115 \mathrm{DEPI}-0.172$ SGAI - 0.327 LEV + 4.697 TATA

Tabel 2. Variabel Dependen

\begin{tabular}{|c|c|c|}
\hline No & $\begin{array}{l}\text { Rasio } \\
\text { Keterangan } \\
\text { DSRI }\end{array}$ & $\begin{array}{l}\text { Rasio } \\
\text { (Net Receivablest / Salest) / (Net Receivablest-1 / Salest-1) }\end{array}$ \\
\hline 2 & GMI & {$\left[\left(\right.\right.$ Sales $\left._{t-1}-\mathrm{COGS}_{t 1}\right) /$ Salest $\left._{t-1}\right] /\left[\left(\right.\right.$ Sales $_{t}$ - COG St $) /$ Salest $]$} \\
\hline 3 & $\mathrm{AOQ}$ & 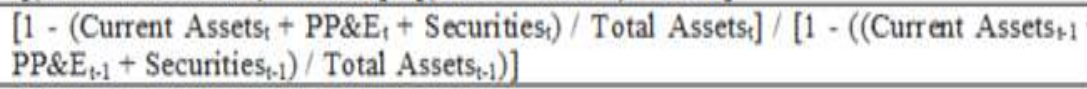 \\
\hline 4 & SGI & Sales $_{t} /$ Sales $_{t, 1}$ \\
\hline $\begin{array}{l}5 \\
6\end{array}$ & $\begin{array}{l}\text { DEPI } \\
\text { SGAI }\end{array}$ & 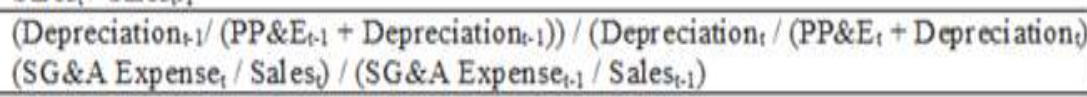 \\
\hline 7 & LVGI & $\begin{array}{l}\left.\left.\text { [(Current Liabilities } s_{1}+\text { Total Long Term Debt }\right) / \text { Total Assets }\right] /\left[\left(\text { Current Liabilities } s_{t-1}\right.\right. \\
\left.\left.\text { Total Long Term Debt } t_{t-1}\right) / \text { Total Assets } s_{t-1}\right]\end{array}$ \\
\hline 8 & TATA & (Income from Continuing Operationst - Cash Flows from Operationst) / Total Assetst \\
\hline
\end{tabular}

\subsection{Variabel Independen}

Variabel independen yang digunakan adalah:

\section{Financial Stability}

Kondisi keuangan stabil jika dapat menutupi kebutuhan yang bersifat rutin dan mendadak tanpa memberikan ancaman secara finansial kepada perusahaan.

Agrow $=$ Total Aset $(t)-$ Total Aset $(t-1)$

Total Aset $(t-1)$

Sumber: Skousen et al. (2009)

\section{Financial Target}

Keadaan dimana perusahaan menggunakan assetnya untuk memperoleh laba perusahaan. Manajer akan mendapatkan tekanan lebih jika tidak dapat memenuhi target perusahaan Rumus Return on Asset

Net Income

$\mathrm{ROA}=$

Average Total Asset

Sumber: Rose, (2014)

\section{External Pressure}

Pressure yang diberikan kepada manajer untuk dapat memenuhi target pihak ketiga. Salah satu tekanan dari pihak eksternal terutama dari kreditor. (Wahyuni \& Budiwitjaksono, 2017)

$$
\text { Lev }=\frac{\text { Total Debt }}{\begin{array}{c}
\text { Total Equity } \\
\text { Sumber: Van Horne (2002) }
\end{array}}
$$




\section{Ineffective Monitoring}

Perusahaan memiliki internal kontrol lemah, dan kurangnya pengawasan dalam kinerja operasional perusahaan. Rumus Ineffective Monitoring:

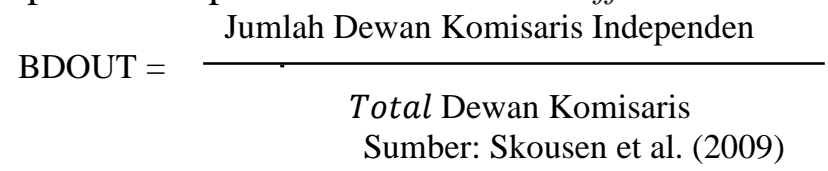

\section{Nature of Industry}

Nature of Industry diproksikan dengan rasio RPT,dimana rasio ini melakukan perhitungan dengan membandingkan total piutang pihak istimewa dengan total piutang perusahaan. Rumus RPT sebagai berikut:

$$
\text { RPT }=\frac{\text { Total Piutang Pihak Istimewa }}{\begin{array}{c}
\text { Total Piutang Perusahaan } \\
\text { Sumber: Skousen et al. (2009) }
\end{array}}
$$

\section{Rationalization}

Rationalization sifatnya situsional, pelaku fraud merasa apa yang dilakukan adalah pembenaran.

TATA $=$

$$
\text { Net Income From Continuing Operations - Cash Flow From Operations }
$$

\section{Total Asset}

Sumber: The Detection of Earnings Manipulation: Messod D. Beneish (1999)

\section{Capability}

Capabilty merupakan seberapa besar seseorang melakukan fraud dilingkungan kerja. proksi pergantian direksi yang disimbolkan dengan DCHANGE. Capability diukur berdasarkan jumlah pergantian dewan direksi Jika terdapat pergantian direksi pada periode t maka diberi angka 1 dan jika tidak terdapat pergantian direksi pada periode t diberikan angka 0 .

8. Arrogance

Arrogance diproksikan dengan rasio kepemilikan manajerial, rasio ini dapat ditunjukan dengan melihat perbandingan jumlah kepemilikan saham yang dimiliki oleh manajemen dengan total jumlah saham perusahaan. Rumus

perhitungan rasio OSHIP adalah sebagai berikut:

$$
\text { OSHIP }=\frac{\text { Total Saham Dimiliki Oleh Manaje }}{\text { Total Jumlah Saham Beredar }}
$$

Sumber: Skousen et al. (2009)

\section{HASIL PENELITIAN DAN PEMBAHASAN 4.1 Analisis Statistik Deskriptif}

Statistik deskriptif dilakukan untuk memberikan gambaran terkait karakteristik dari setiap variabel penelitian

Tabel 3. Statistik Deskriptif

\begin{tabular}{|l|l|l|l|l|l|l|}
\hline & $\mathrm{N}$ & Mnimum & Maximum & Sum & Mean & Std. Deviation \\
\hline AGROW & 189 & -.410 & .639 & 21.509 & .11380 & .145198 \\
\hline LEV & 189 & -2.215 & 4.190 & 147.797 & .78199 & .862810 \\
\hline BDOUT & 189 & .000 & .667 & 69.645 & .36849 & .143903 \\
\hline
\end{tabular}




\begin{tabular}{|l|l|l|l|l|l|l|}
\hline RPT & 189 & .000 & .993 & 34.736 & .18379 & .290445 \\
\hline TATA & 189 & -.247 & .228 & 6.285 & .03325 & .075020 \\
\hline DCHANGE & 189 & .0 & 2.0 & 78.0 & .413 & .5147 \\
\hline OSHIP & 189 & .000 & .873 & 9.941 & .05260 & .127255 \\
\hline ROA & 189 & -.085 & 226.714 & 337.482 & 1.78562 & 17.114059 \\
\hline FFR & 189 & -3.536 & -.115 & -401.271 & -2.12313 & .564260 \\
\hline Valid N (listwise) & 189 & & & & & \\
\hline
\end{tabular}

\subsection{Analisis Uji Hipotesis}

Tabel 4. Uji Koefisien Determinasi

\begin{tabular}{|c|c|c|c|c|}
\hline \multicolumn{5}{|c|}{ Model Summaryb } \\
\hline Model & $\mathrm{R}$ & R Square & $\begin{array}{ll}\text { Adjusted } & R \\
\text { Square } & \end{array}$ & $\begin{array}{l}\text { Std. Error of the } \\
\text { Estimate }\end{array}$ \\
\hline 1 & $.720^{\mathrm{a}}$ & .518 & .496 & .400403 \\
\hline \multicolumn{5}{|c|}{$\begin{array}{l}\text { a. Predictors: (Constant), OSHIP, AGROW, ROA, RPT, LEV, BDOUT, } \\
\text { TATA, DCHANGE }\end{array}$} \\
\hline
\end{tabular}

Nilai koefisien (R) yang lebih besar dari 0,5 dan lebih kecil dari 1 sehingga data menunjukkan senilai 0,720 atau $72,0 \%$. Nilai Adjusted sebesar 0,496 sehingga dapat diartikan bahwa $\mathrm{R}^{2}$ menyatakan bahwa 49,6\% dan sisanya sebesar 50,4\% dijelaskan oleh variable lain.

Tabel 5. Uji F

\begin{tabular}{|c|c|c|c|c|c|c|}
\hline \multicolumn{7}{|c|}{ ANOVA $^{a}$} \\
\hline \multicolumn{2}{|c|}{ Model } & Sum of Squares & $\mathrm{df}$ & Mean Square & $\mathrm{F}$ & Sig. \\
\hline \multirow[t]{3}{*}{1} & Regression & 30.999 & 8 & 3.875 & 24.169 & $.000^{\mathrm{b}}$ \\
\hline & Residual & 28.858 & 180 & .160 & & \\
\hline & Total & 59.857 & 188 & & & \\
\hline
\end{tabular}

Hasil dari uji $\mathrm{F}$, tingkat signifikansi $<0,05$ sebesar 0,000 . Sehingga model penelitian dapat diartikan bahwa variabel independent yang terdiri dari AGROW, ROA, TATA, DCHANGE, LEV, BDOUT, RPT, OSHIP, secara simultan mempengaruhi variabel dependen, fraudulent financial statement

Tabel 6. Uji T

\begin{tabular}{|c|c|c|c|c|c|c|}
\hline \multicolumn{7}{|c|}{ Coefficients $^{a}$} \\
\hline \multirow{2}{*}{\multicolumn{2}{|c|}{ Model }} & \multicolumn{2}{|c|}{ Unstandardized Coefficients } & \multirow{2}{*}{\begin{tabular}{|l} 
Standardized \\
Coefficients \\
Beta \\
\end{tabular}} & \multirow[b]{2}{*}{ t } & \multirow[b]{2}{*}{ Sig. } \\
\hline & & B & Std. Error & & & \\
\hline \multirow[t]{9}{*}{1} & (Constant) & -2.099 & .099 & & -21.151 & .000 \\
\hline & AGROW & .622 & .210 & .160 & 2.962 & .003 \\
\hline & $\mathrm{ROA}$ & .000 & .002 & .015 & .284 & .777 \\
\hline & LEV & -.042 & .034 & -.065 & -1.226 & .222 \\
\hline & BDOUT & -.396 & .207 & -.101 & -1.908 & .058 \\
\hline & RPT & .020 & .103 & .010 & .190 & .849 \\
\hline & TATA & 4.703 & .403 & .625 & 11.682 & .000 \\
\hline & DCHANGE & -.121 & .060 & -.111 & -2.030 & .044 \\
\hline & OSHIP & -.506 & .242 & -.114 & -2.092 & .038 \\
\hline
\end{tabular}




\subsection{Hasil Uji Statistik T}

Nilai prob t Agrow sebesar $0.003<0.05$, maka Hal diterima. Variabel Financial Stability berpengaruh positif dan signifikan terhadap FFR. Setiap terjadinya perubahan kenaikan aset, akan menaikkan resiko terjadinya kecurangan, perubahan rasio kenaikan aset mmberikan pressure bagi manajemen jika kondisi keuangan perusahaan tidak stabil.

Nilai prob t ROA sebesar $0.777>0.05$, maka Ha2 ditolak. Variabel Financial Target memiliki pengaruh positif dan tidak signifikan terhadap FFR. Penggunaan asset yang tidak efektif didalam suatu perusahaan dapat menghasilkan keuntungan yang tidak maksimal, manajemen akan mengalami pressure untuk selalu mempertahankan laba yang telah dihasilkan dari periode sebelumnya.

Nilai prob t $L E V$ sebesar $0.222>0.05$, maka Ha3 ditolak. Hal ini berarti variabel External Pressure memiliki pengaruh negatif dan tidak signifikan terhadap FFR. Tekanan ini diakibatkan dari pihak eksternal terutama kreditor karena perusahaan tidak mampu untuk membayar hutangnya sehingga perusahaan kesulitan untuk mendapatkan pendanaan berupa pinjaman dari pihak kreditor untuk membiayai riset, ekspansi, dan pengeluaran lainnya untuk menjalankan kegiatan operasional perusahaan. Namun disisi lain perusahaan harus melunasi hutangnya kepada kreditor.

Nilai prob t BDOUT sebesar $0.058>0.05$, maka Ha4 ditolak. Hal ini berarti variabel Ineffective Monitoring memiliki pengaruh negatif dan tidak signifikan. Jumlah dewan komisaris independen yang mengawasi manajemen tidak terlalu mempengaruhi dan bukan hal yang terlalu diperhatikan, melainkan yang terpenting adalah efektivitas kinerja dewan komisaris tersebut. Dewan komisaris independen tidak terafiliasi ataupun tidak memahami peraturan di perusahaan, sehingga perusahaan tetap bisa terindikasi fraud walaupun didalamnya terdapat dewan komisaris independen.

Nilai prob t $R P T$ sebesar $0.849>0.05$, maka Ha5 ditolak. Hal ini berarti variabel Nature of Industry memiliki pengaruh positif dan tidak signifikan terhadap FFR.. Risiko inheren jadi tinggi ketika pihak perusahaan melakukan transaksi dengan related parties karena peraturan serta keterlibatan dari manajemen yang tinggi ini dapat membuat keputusan yang subjektif, sehingga salah saji material dapat menjadi tinggi.

Nilai prob t TATA sebesar $0.0000<0.05$, maka Ha6 diterima. Hal ini berarti variabel Rationalization berpengaruh positif signifikan terhadap FFR. Discretionary accrual dimana manager melakukan memanipulasi pendapatan perusahaan dengan melakukan pengungkapan estimasi pencatatan yang salah ketika transaksi terjadi, sehingga jika nilai discretionary accrual naik maka kemungkinan fraudulent financial reporting naik

Nilai prob t Dchange adalah sebesar $0.044<0.05$, maka Ha7 diterima. Hal ini berarti variabel Capability memiliki pengaruh negatif dan signifikan terhadap FFR. Setiap kinerja dari direksi akan selalu diawasi dan pergantian direksi bisa menjadi suatu tindakan yang diberikan dengan harapan jika melakukan pergantian direksi yang baru dapat menjadikan operasional perusahaan lebih berkompeten dari direksi sebelumnya

Nilai prob t $O S H I P$ adalah sebesar $0.038<0.05$, maka Ha8 diterima. Hal ini. Hal ini bisa dikarenakan shareholder yang memiliki kekuasaan dari segi kepemilikan berhak melakukan pengambilan keputusan untuk operasional perusahaan dan shareholder dapat dijadikan penghubung antara prinsipal dan agen.

\section{KESIMPULAN, KETERBATASAN DAN SARAN}

5.1. Kesimpulan

1. Ha1 diterima. Hal ini menjelaskan bahwa Agrow memilik pengaruh positif terhadap fraudulent financial statement. Adanya tekanan yang didapatkan oleh agen akan 
memberikan dorongan untuk melakukan fraud. Agen dituntut untuk selalu memberikan laporan keuangan yang baik sehingga perusahaan akan terlihat bagus dari sisi performa keuangan.

2. Ha2 ditolak. Hal ini menjelaskan ROA memiliki pengaruh positif terhadap fraudulent financial statement namun tidak signifikan. Apabila manajer tidak mencapai target, kecenderungan untuk mengahsilkan laporan yang dimanipulasi menjadi tinggi dikarenakan keinginann untuk mendapatkan bonus atas kinerja yang telah dilakukan.

3. Ha3 ditolak. Hal ini menjelaskan bahwa Debt memiliki pengaruh negative terhadap fraudulent financial statement namun tidak berpengaruh signifikan. Komponen hutang yang tinggi tidak selalu memiliki arti negatif, dikarenakan hutang yang didapatkan dapat digunakan untuk melakukan ekspansi, pengembangan produk baru ataupun berdampak positif terhadap kinerja operasional perusahaan.

4. Ha4 ditolak. Hal ini menjelaskan RPT memiliki pengaruh positif terhadap fraudulent financial statement namun tidak signifikan. Resiko bawaan menjadi tinggi atas transaksi induk dan anak dikarenakan agen memiliki wewenang untuk menentukan keputusan yang secara subjektif sehingga salah saji material menjadi tinggi pada laporan keuangan.

5. Ha5 ditolak. Hal ini menjelaskan bahwa IM memiliki pengaruh negatif terhadap fraudulent financial statement namun tidak signifikan. Sebuah perusahaan tidak boleh hanya mengandalkan dewan komisaris independent, namun harus memiliki internal kontrol yang baik dan direview secara berkala. nternal control yang efektif akan memberikan jaminan dalam mencapai tujuan organisasi dan merupakan suatu ukuran dari keamanan internal organisasi.

6. Ha6 diterima. Hal ini menjelaskan bahwa TATA memiliki pengaruh positif terhadap fraudulent financial statement. Agen memiliki hak untuk menentukan besaran total aktrual yang akan digunakan setiap transaksi keuangan. Hal ini memberikan peluang fraud apabila total akrual yang ditetapkan berbeda dari tahun ke tahun.

7. Ha7 diterima. Hal ini menjelaskan bahwa Dchange memiliki pengaruh negatif terhadap fraudulent financial statement. Pergantian direksi ditentukan didalam Rapat Umum Pemegang Saham oleh para shareholders dan stakeholders. Pergantian direksi dapat dilakukan dengan berbagai keputusan seperti kurang compatible, tidak memenuhi target ataupun tidak dapat dipercaya.

8. Ha8 diterima Hal ini menjelaskan bahwa Oship memiliki pengaruh negatif terhadap fraudulent financial statement. Hal ini menjelaskan agen memiliki saham di perusahaan akan berusahan membuat laporan keuangannya menjadi lebih baik sehingga performa agen akan meningkat dikarenakan agen ingin mendapatkan keuntungan dari investasi dan bonus yang didapatkan.

\subsection{Keterbatasan}

Berdasarkan hasil analisis dan pembahasan yang telah dilakukan, terdapat beberapa keterbatasan dalam penelitian ini, yaitu:

1. Penelitian hanya dilakukan pada perusahan manufaktur yang terdaftar di Bursa Efek Indonesia selama periode 2014-2018, perusahaan yang menggunakan nilai mata uang rupiah dalam laporan keuangan secara berturut-turut dan perusahaan yang telah menerbitkan laporan keuangan tahunan dan sudah diaudit oleh auditor independen. Sehingga, hasil penelitian ini tidak sepenuhnya mewakili perusahaan manufaktur yang ada di Indonesia. 
2. Variabel yang digunakan dalam penelitian ini terbatas, dimana peneliti hanya menggunakan rasio asset growth, return on asset, leverage, ineffective monitoring, related parties transactions, total accrual to total asset, change in board director dan kepemilikan manajerial dalam penelitian ini. Sedangkan, masih ada banyak faktor lain yang dapat mempengaruhi kemungkinan fraudulent financial reporting dalam sebuah perusahaan.

\section{REFERENSI}

Amara, I., Amar, A. B., \& Jarboui, A. (2013). Detection of Fraud in Financial Statements: French Companies as a Case Study. International Journal of Academic Research in Business and Social Sciences, Vol. 3, No. 5 ISSN: 2222-6990 .

American Institute of Certified Public Accountants. (2002). SAS No. 99 Consideration of Fraud in a Financial Statement Audit, Statement on Auditing Standard No. 99. New York: AICPA.

Aprillia, Cicilia, O., \& Sergius, R. P. (2015). The Effectiviness of Fraud Triangle On Detecting Fraudulent Financial Statement: Using Beneish Model And The Case of Special Companies. Jurnal Riset Akuntansi dan Keuangan Vol.3 .

Association of Certified Fraud Examiners (ACFE). (2017). Report to the Nations Occupational Fraud and Abuse. USA.

Darmawan, A., \& Saragih, S. O. (2017). The Impact of Auditor Quality, Financial Stability, and Financial Target for Fraudulent Financial Statement. Journal of Applied Accounting and Taxation Vol. 2, No. 1 e-ISSN: 2548-9925 , 9-14.

Ghozali, I. (2012). Aplikasi Analisis Multivariate Dengan Program IBM SPSS 20 . Semarang: Badan Penerbit Universitas Diponegoro.

Hery. (2016). Auditing dan Asurans Pemeriksaan Akutansi Berbasis Standar Audit

International. Jakarta: PT Grasindo.

Ikatan Akuntansi Indonesia (IAI). (2009). Pernyataan Standar Akutansi Keuangan (PSAK) No 1: Penyajian Laporan Keuangan . Jakarta: IAI.

Jefri, R., \& Mediaty. (2014). Pendekteksian Kecurangan (Fraud) Laporan Keuangan. Jurnal Akutansi ISSN 2339-1502 Vol. 01 No. 02, 56-64.

Jensen, Michael C. Dan W.H. Meckling. (1976). "Theory of The Firm: Managerial Behavior, Agency Cost and Ownership Structure". Journal of Financial Economics 3. hal. 305360.

Kusumaningsih, K. U., \& Wirajaya, I. G. (2017). Faktor-Faktor Yang Mempengaruhi Tindak Kecurangan di Perusahaan Perbankan. ISSN: 2302-8556, E-Jurnal Akuntansi Universitas Udayana, Vol.19.3. , 1832-1860.

Mahenthiran, S. (2017). Determinants of Fraudulent Financial Reporting: Evidence from Malaysia. Jurnal Pengurusan 42, 103 - 117.

Omar, N., \& Johari, Z. A. (2017). Predicting fraudulent financial reporting using artificial neural network. Journal of Financial Crime, Vol. 24 Issue: 2 , 362-387.

Omoye, A. S., \& Eragbhe, E. (2014). Accounting Ratios and False Financial Statements Detection: Evidence from Nigerian Quoted Companies. International Journal of Business and Social Science Vol. 5, No. 7(1).

Repousis, S. (2016). Using Beneish Model To Detect Corporate Financial Statement Fraud In Greece. Emerald Insight Journal of Financial Crime, Vol. 23 Issue: 4, 1063-1073.

Rose, Westerfield, \& Jordan. (2012). Fundamentals of Corporate FInance. New York: McGrawHill. 
Sekaran, U., \& Bougie, R. (2010). Research Method For Business: A Skill-Building Approach, Fifth Edition. Great Britain: John Wiley \& Sons Limited.

Sihombing, K. S., \& Rahardjo, S. N. (2014). Analisis Fraud Diamond Dalam Mendeteksi Financial Statement Fraud : Studi Empiris Pada Perusahaan Manufaktur Yang Terdaftar di Bursa Efek Indonesia. Diponegoro Journal of Accounting Volume 03, Nomor 02, , 1-12.

Skousen, C. J., Smith, K. R., \& Wright, C. J. (2009). Detecting and Predicting Financial Statement Fraud: The Effectiveness of the Fraud Triangle and SAS No. 99. Emerald insgiht, Vol. 13: 1-39.

Sunardi , \& Amin, N. (2018). Fraud detection of financial statement by using fraud diamond perspective. International Journal of Development and Sustainability , 878 - 891.

Wolfe, D. T., \& Hermanson, D. R. (2014). The Fraud Diamond: Considering the Four Elements of Fraud. The CPA Journal: , 38-42. 